\begin{tabular}{|l|l|l|l|}
\hline $\begin{array}{l}\text { Eiszeitalter und Gegenwart } \\
\text { Quaternary Science Journal }\end{array}$ & $\mathbf{5 6 / 3}$ & $212-227$ & Hannover 2007 \\
\hline
\end{tabular}

\title{
The Upper Pleistocene loess/palaeosol sequence from Schatthausen in North Baden-Württemberg
}

\author{
Manfred Frechen, Birgit Terhorst \& Wolfgang Rähle ${ }^{*}$
}

Keywords: loess, palaeosol, luminescence dating, palaeoclimate, mollusc, Pleistocene, Germany

\begin{abstract}
The loess/palaeosol sequence from the section at Schatthausen in North Baden-Württemberg gives evidence for a younger Bt horizon superimposing the last interglacial palaeosol. This result requires a more careful investigation of polygenetic superimposed palaeosols to avoid misinterpretation of the chronostratigraphic positions. The humic horizon and the underlying Bt horizon were most likely formed during two soil forming periods, as evidenced by means of palaeopedology, phytoliths and luminescence dating. The lowermost Bt horizon (Bt1) was most likely formed during the Eemian interglacial, marine isotope substage

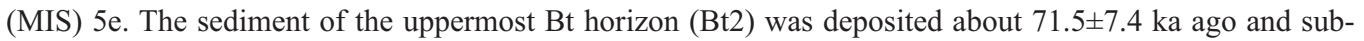
sequently superimposed by soil formation most likely during early MIS 3 . The Ah horizon covering the Bt gave infrared optically stimulated luminescence (IRSL) age estimates between $52.5 \pm 5.5 \mathrm{ka}$ and $45.4 \pm 4.7 \mathrm{ka}$ confirming soil formation during MIS 3. Periods of increased dust accumulation rates can be distinguished for the loess/palaeosol sequence by IRSL age estimates. These are from the youngest to the oldest: the Late glacial loess (MIS 2) with a weighted mean age of $15.2 \pm 0.6 \mathrm{ka}(\mathrm{n}=7)$, the Middle Pleniglacial sediments (MIS 3) with a weighted mean age of $48.9 \pm 2.5 \mathrm{ka}(\mathrm{n}=4)$ and the Lower Pleniglacial/Early Glacial sediments (MIS 4/MIS 5) with a deposition age of 71.5 $\pm 7.4 \mathrm{ka}$ and older loess deposits. The IRSL age estimates are in excellent agreement with the geological estimates and correlate well with the dust peaks of the Greenland Icecore record (GRIP). The loess record from Schatthausen complements the loess/palaeosol sequence from the nearby Nußloch section with the late glacial loess and its intercalated Cryic Gleysols.
\end{abstract}

\section{[Die oberpleistozäne Löss-/Paläobodenabfolge von Schatthausen im nördlichen Baden-Württemberg]}

Zusammenfassung: In der Löss-/Paläobodenabfolge des Profils Schatthausen aus dem nördlichen BadenWürttemberg ist den Lössen ein Bt-Horizont oberhalb eines letztinterglazialen Paläobodens zwischengeschaltet. Diese Befunde fordern eine genauere Untersuchung von polygenetisch überprägten Paläoböden, um eine mögliche chronostratigraphische Fehlinterpretation zu vermeiden. Der Humushorizont und der darunter liegende Bt-Horizont entstanden während zweier Bodenbildungsphasen. Diese Annahme wird durch paläopedologische Befunde, Phytolithe und Lumineszenz-Datierungen unterstützt. Der untere Bt-Horizont (Bt1) wurde vermutlich während des Eem gebildet. Die Sedimente des obersten Bt-Horizontes (Bt2) wurden um $71.5 \pm 7.4$ ka abgelagert und durch eine Bodenbildung, vermutlich während des Mittelwürm, überprägt. Die Sedimente des Ah-Horizontes des Bt2-Horizonts ergaben Infrarot Optisch Stimulierte Lumineszenz (IRSL)

* Anschrift der Verfasser: Prof. Dr. M. Frechen, Leibniz Institute for Applied Geosciences (GGAInstitut), Geochronology and Isotope Hydrology Section, Stilleweg 2, 30655 Hannover, Germany, manfred.frechen@gga-hannover.de

Apl.-Prof. Dr. B. Terhorst Institut für Geographie und Regionalforschung, Althanstraße 14, A1180 Wien, birgit.terhorst@univie.ac.at

DR. W. RÄHLE, Universität Tübingen, Geographisches Institut, Hölderlinstr. 12, 72074 Tübingen, Germany 
-Datierungen zwischen $52.5 \pm 5.5 \mathrm{ka}$ und $45.4 \pm 4.7 \mathrm{ka}$ und bestätigen eine Bodenbildung während des Mittelwürm. Perioden unterschiedlicher Staubakkumulation können durch IRSL-Datierungen im Profil quantitativ unterschieden werden: der spätglaziale Löss mit einem gewichteten Alter von $15.2 \pm 0.6 \mathrm{ka}(\mathrm{n}=7)$, die mittelwürmzeitlichen Sedimente und einem gewichteten Alter von $48.9 \pm 2.5 \mathrm{ka}(\mathrm{n}=4)$ und die frühwürmzeitlichen Sedimente mit einem Ablagerungsalter von 71.5 7.4 ka sowie nicht physikalisch datierte ältere Lösse.

Die IRSL-Alter sind in guter Übereinstimmung mit den geologisch erwarteten Ergebnissen und korrelieren sehr gut mit den letztglazialen Perioden maximaler Staubakkumulationsraten aus Grönland (GRIP-Eisbohrkern). Die Lössabfolge von Schatthausen ergänzt die gut gegliederte letztinterglaziale/letztglaziale Löss-Sequenz des benachbarten Nußloch-Profils um den spätglazialen Löss und seine zwischengeschalteten Nassböden.

\section{Introduction}

In Germany, the term “Löß” (loess) was first reported by Carl Caesar von LEONHARD (1823/24) who described yellowish brown, silty deposits from a section near Heidelberg. LyELL (1834) brought the term into widespread usage by visiting the Rhine and Mississippi Valleys observing the similarity of loess and loess derivatives in both areas. The aeolian origin of loess has been accepted since the work of Virlet d AousT (1857) and RichthofEN's (1878) observation and interpretation of loess from China. Loess deposits and the intercalated palaeosols display a wide variety of climate proxies, and supply some clues about terrestrial climate and environmental changes during the Middle and Upper Pleistocene. The last glacial loess record has become of major interest because chronological methods like thermoluminescence (TL) and optically stimulated luminescence (OSL) have recently been improved significantly enabling the direct dating of the deposition age of aeolian sediments. High-resolution luminescence dating studies with a large number of samples were successfully applied to Upper Pleistocene loess and loess derivatives in Germany and elsewhere (FRECHEN 1994, 1999; FrECHEN et al. 1997, 1999, 2001; LANG et al. 2003; ZöLLER et al. 1994).

During the last glacial period, North BadenWürttemberg experienced periglacial conditions, which were characteristic in Central Europe for the time being. Thick deposits of calcareous loess subdivided by palaeosols are widespread. The main source of the silt-rich dust is situated in the floodplain of the Rhine valley (FRECHEN et al. 2003), which is located about $20 \mathrm{~km}$ to the west of the section under study.

A general pedostratigraphical scheme was set up for the last interglacial/glacial loess record by Bibus (1989), Schönhals et al. (1964) and Semmel (1967, 1968, 1996, 1999), and for the penultimate interglacial/glacial record by Bibus (1974, 1995) and BiBus et al. (1996). Several studies have been more recently published about loess stratigraphy in the Middle Neckar area and the Rhine-Main area (cp. Bibus 1989; Bibus et al. 1996; FreChen 1999; ZöLLER \& LösChER 1999; ANTOINE et al. 2001). RoHDEnburg \& Meyer (1966) and RöSNer (1990) described the formation of brown forest soils during the last interglacial but also during interstadials of the early last glacial (Early Würmian). TERHORST et al. (2001) investigated the section at Schatthausen by means of palaeopedology and rock magnetic properties. This loess/palaeosol sequence includes stratigraphically part of the last interglacial/glacial record with the Eemian interglacial soil and last glacial interstadial soils. In general, magnetic susceptibility measurements show that magnetic minerals are sensitive in respect to weak soil forming processes, different horizons in soil profiles and hydromorphic features in soils and sediments.

The aim of this study is to set up a more reliable chronological framework for the climatic variations recorded in loess-palaeosol sequences during the last interglacial/glacial period. In particular, the study focuses on the pedogenetic complexes on top of the Eemian palaeosol and their stratigraphical meaning. 


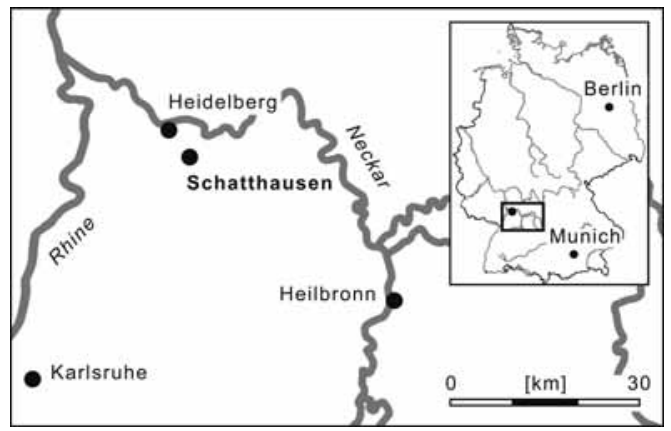

Fig. 1: Map showing the locality of the sections at Schatthausen and Nussloch in the Upper Neckar valley.

\section{The Loess Record}

The profile under study is located in the abandoned loess pit "Sandritter" near Schatthausen situated between the villages Maisbach and Nußloch to the southeast of Heidelberg (Fig. 1). The altitude is $220 \mathrm{~m}$ above sea level and the coordinates of the section of interest are R3492000 and H5452750 following the GaussKrüger coordinates of German topographic maps (scale 1:25.000). A succession of NNW to SSE elongated gredas with a thickness of 15-20 $\mathrm{m}$ and a length of 2-4 $\mathrm{km}$ are separated by small dry valleys (AnToIne et al. 2001). The profile under study, Schatthausen B, is located within a palaeovalley, which is not visible in the present relief, close to the famous Nussloch loess site studied recently by ANTOINE et al. (2001).

The lower part of the sequence consists of laminated sediments superimposed by a reddish brown interglacial Bt horizon (WRB 1998), which correlates most likely with the Eemian interglacial, marine isotope substage (MIS) 5e (Fig. 2, SH 17). This Bt horizon formed on top of the penultimate glacial Cryic Gleysols ("Bruchköbeler Nassböden" sensu BiBus 1974). The upper part of the Bt horizon is truncated, as described for many other loess/ palaeosol sequences in the study area (BENTE \& LösCHER 1987). Sediments of the last glacial period reach a thickness of about $6.50 \mathrm{~m}$ and cover the truncated Eemian Luvisol and older loess deposits. The transition from interglacial to glacial climatic conditions is recorded by an erosional discontinuity and the subsequently deposited pedosediments including rounded charcoal pieces of Larix, Picea and Betula (Fig. 2; SH16), as determined by W. Schoch (Adliswill, Switzerland). These charcoal pieces are most likely the remains of boreal forest fires. Similar horizons enriched with charcoal have been described from equivalent stratigraphic positions in many loess profiles (cp. RoHDENBurg 1968; SchÖNHALS et al. 1964; Ricken 1983; RöSNER 1990; FreChEN et al. 1999).

The pedosediment was affected by interstadial soil forming processes, which can be recognized along the whole profile wall (Fig. 2; SH16 - SH13). The uppermost horizon of the pedocomplex consists of a degraded and decalcified humic-rich horizon with crotovinas. The pedocomplex can be distinguished into a dark brown Ah horizon (SH13) and a dark yellowish brown AhE horizon (SH14). An AhBt horizon (SH15) and a weakly lessivated Bt horizon (SH16) are exposed below. It is important to note that the weakly developed $\mathrm{Bt}$ horizon ( $\mathrm{SH}$ 16) is superimposed on the strongly developed interglacial palaeosol (SH 17) and, thus postdates the Eemian. The described pedocomplex (SH $16-\mathrm{SH} 13$ ) including a relatively thick Ah and AhE horizon is similar to that of grey forest soils, respectively Phaeozems (WRB 1998), as described in the Russian literature (e.g. GERASIMOVA et al. 1996). This soil type is designated to correlate with a polygenetic soil formation because the upper humic-rich horizon was formed in a second period of soil formation after the lessivation (cp. PÉCSI \& Richter 1996; Gerasimova et al. 1996). The study of autochthonous opal phytoliths sampled from horizons SH13 - SH 15 yielded two different spectra. The first spectrum gave 36\% phytoliths indicating a typical forest steppe environment of conifers and $9 \%$ phytoliths of forest grass and herbs. The second spectrum, which is present in the humic zone of SH13, gave $17 \%$ of phytoliths of grass steppe environment, as determined by A. Golyeva (Geographical Institute, Moscow). The palaeobotanical studies confirm a polygenetic and multiphase soil forming process for the lower part of the sequence. The upper humic-rich horizon is covered by a light 
Im



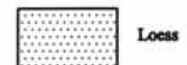

Loess

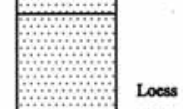

SH9

SH9a (a)

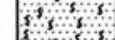

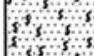

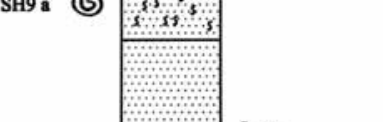

Loess

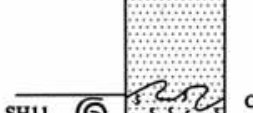

SH12b G

SH12 a G

䑁

Ah (Mosbacher

Humuszone)

AhE

$\mathrm{ABt}$

Bt1

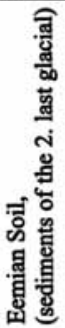

$(9,10 \mathrm{~m})$

\begin{tabular}{|llcl|}
\hline sample & $\begin{array}{l}\text { IRSL ages } \\
\text { (ka) }\end{array}$ & $\begin{array}{l}\text { TL ages } \\
(\mathbf{k a})\end{array}$ & ${ }^{14} \mathrm{C}$ ages \\
\hline SH1 & $12.5 \pm 1.2$ & $12.7 \pm 1.2$ & $\begin{array}{l}10.146-10.139^{*} 1 \\
\text { (cal; UtC10624) }\end{array}$ \\
\hline
\end{tabular}

SH2

$17.0 \pm 1.8$

SH3

$13.6 \pm 1.4$

$19.5 \pm 2.3$

10.220-10.183 *1

$13.9( \pm 1.7)$

SH5

$20.3 \pm 2.2$

$23.2 \pm 2.8$

SH6

SH7

$14.6 \pm 2.3$

$13.5 \pm 1.8$

SH8

$16.0 \pm 1.7$

SH9

$17.4 \pm 1.8$

$16.3 \pm 2.1$

$23.990 \pm 160$

(UtC10626)

$24.510 \pm 190$

(UtC10628)

$16.4 \pm 1.7$

$17.0 \pm 1.8$

SH10

SH11

$38.5 \pm 4.0$

SH12

$51.6 \pm 5.2$

SH13

$45.4 \pm 4.7$

SH14

$52.5 \pm 5.5$

$47.6 \pm 4.9$

SH16

$71.5( \pm 7.4)$

SH17

SH18

Fig. 2: Lithological results, luminescence age estimates including IRSL and TL and radiocarbon ages from the loess/paleosol sequence at Schatthausen. 
olive-brown coloured Bw horizon (SH12) intercalated between the early Middle Würmian and the early Upper Würmian Cryic Gleysols. This weakly developed palaeosol does not have the characteristics of the "Lohner Boden (Lohne soil)" sensu Rohdenburg \& SEMmel (1971) and Semmel (1968), which is supposed to correlate with the Denekamp interstadial at the end of MIS 3 or at the beginning of MIS 2 . The Bw horizon probably correlates with the "Böckinger Boden" following BiBus (1989) and formed prior to the Denekamp interstadial ("Lohner Boden"). The IRSL age estimates range from $51.6 \pm 5.2$ to $38.5 \pm 4.0 \mathrm{ka}$ and confirm a deposition of the sediment prior to the Denekamp interstadial. Furthermore, this interstadial soil (Bw horizon) is superimposed by a light greyish Cryic Gleysol (SH11, 2.5Y $7 / 2$ ) showing pushed cryoturbation features with cone-shaped and tongue-like structures inserted into the underlying palaeosol. These properties indicate a cold period during the Middle Würmian (MIS 3). The Middle Pleniglacial record is poorly preserved and covered by Upper Pleniglacial calcareous loess about 5 $\mathrm{m}$ thick (SH $10-\mathrm{SH}$ 1) and intercalated by at least three Cryic Gleysols. These Gleysols do not show the characteristic features of the Upper Würmian Gleysols, as described by SEMMEL (1968).

The lowermost Cryic Gleysol is covered by a weak brown $\mathrm{BC}$ horizon (SH 7, 6). The loess deposits above the brownish horizon are subdivided by two weak Cryic Gleysols. Stratigrapically, this part of the sequence may correlate with the E4 and E5 "Erbenheimer Böden" sen$s u$ Semmel (1968). The Eltville tephra, defined as stratigraphical marker horizon for the Upper Pleniglacial, has not been found.

However, three Cryic Gleysols and one weak brownish BC horizon are intercalated in the Upper Würmian loess. A correlation with the "Erbenheimer Böden" according to SEMMEL $(1967,1968)$ is suggested but remains uncertain. The problems of Upper Würmian loess stratigraphy in the area under study is under discussion (cp. Semmel 1967; Antoine et al. 2001). According to Antorne et al. (2001), the Upper Würmian loess record, which correlates to MIS 2, gives evidence for more weak cli- matic fluctuations than previously thought (cp. Semmel 1967), similar to those described in the Greenland ice core record (NORTHGRIP 2004).

\section{Malacozoology}

Malacozoological studies were carried out to study the palaeoenvironmental conditions of the loess sequence under study in more detail. Five samples were taken containing numerous shells and shell fragments: two originating from the BC horizon (SH12a and SH12b), one from the Cryic Gleysol (SH11) immediately above the $\mathrm{BC}$ horizon and two were taken from the next younger Cryic Gleysol (SH9 and SH8, Table 1, Fig. 2).

The mollusk assemblages from the Middle Würmian Bw horizon (SH12a, SH12b and SH11) are similar and reflect interstadial conditions, as evidenced by high dominance values of Vallonia costata and the occurrence of some climatically more demanding species like Vallonia pulchella and Vertigo pygmaea. A correlation with the Middle Würmian is very likely. Towards the overlying Cryic Gleysol (SH9), which is closely linked with the BC horizon, an increase of moisture demanding snails (Succinella oblonga, Vitrea crystallina, slugs) and a decrease of more thermophilous species like Vallonia were detected. Snails, which might indicate a severe cooling, have not been found. It is likely that these faunal changes are linked to climatic changes at the beginning of the following stadial. The described faunas are of open landscape type, suggesting the existence of grassland or herb-rich steppe. Snails associated with more abundantly covered vegetation were not detected.

The two samples originating from the upper Cryic Gleysol (SH9a and SH9b) show a similar composition (Table 1). Both represent the Columella-fauna sensu LozeK (1964). Next to relative high numbers of Columella columella, index species of glacial conditions occur including catholic (Succinella oblonga, Trichia hispida, Clausilia rugosa parvula and others) and open-landscape species (predominantly Pupilla muscorum). Thermophile species have not been found. Vallonia costata indicates a cold and humid climate but is very rare in 
Table 1: Mollusk assemblages from the Würmian loess/palaeosol sequence of Schatthausen. The abundance of species per sample is expressed by dominance rates in \%.

SH12 Middle Würmian Bw horizon ("Böckinger Boden"), a lower part, b middle part

SH11 Middle Würmian Cryic Gleysol on top of Bw horizon

SH9 Upper Würmian Cryic Gleysol, a lower part, b upper part

\begin{tabular}{|c|c|c|c|c|c|}
\hline & SH12a & $\mathrm{SH} 12 \mathrm{~b}$ & SH11 & SH9a & SH9b \\
\hline \multicolumn{6}{|l|}{ Index species of glacials } \\
\hline Columella columella & - & - & - & 24.0 & 11.6 \\
\hline \multicolumn{6}{|c|}{ Common climatic indifferent loess species } \\
\hline Pupilla muscorum & 50.8 & 21.6 & 22.7 & 34.0 & 26.4 \\
\hline Succinella oblonga & 5.7 & 11.0 & 20.1 & 14.7 & 33.3 \\
\hline Trichia hispida & 15.0 & 24.4 & 20.1 & 12.6 & 11.2 \\
\hline \multicolumn{6}{|c|}{ Accidental climatic indifferent loess species } \\
\hline Agriolimacidae/Limacidae & 2.0 & 1.9 & 7.6 & 0.5 & 4.7 \\
\hline Arianta arbustorum & 0.1 & 0.8 & 0.8 & 0.1 & 0.4 \\
\hline Clausilia dubia & - & - & - & 0.1 & - \\
\hline Clausilia rugosa parvula & 0.2 & - & - & 13.4 & 11.6 \\
\hline Cochlicopa lubrica & 0.5 & 1.7 & 3.4 & - & - \\
\hline Eucobresia spec. & - & 0.2 & - & - & - \\
\hline Punctum pygmaeum & 0.3 & - & 2.8 & 0.1 & - \\
\hline Trichia spec. & - & - & - & 0.1 & - \\
\hline Vallonia costata & 20.3 & 30.3 & 11.6 & 0.3 & 0.8 \\
\hline Vitrea crystallina & 0.5 & 3.0 & 10.1 & 0.1 & - \\
\hline \multicolumn{6}{|c|}{ Species correlating mainly to warm phases but also to warmer periods of glacials } \\
\hline Vallonia pulchella & 4.5 & 3.8 & - & - & - \\
\hline Vertigo pygmaea & 0.1 & 1.3 & 0.8 & - & - \\
\hline Number of species & 12 & 11 & 10 & 12 & 8 \\
\hline Number of individuals $(=100 \%)$ & 665 & 472 & 966 & 818 & 258 \\
\hline
\end{tabular}

samples SH9a and SH9b. A correlation of this Cryic Gleysol with the Upper Würmian is very likely.

There is a remarkable coincidence concerning composition and dominance structure between the fauna from the Cryic Gleysol (SH9a and $\mathrm{SH} 9 \mathrm{~b}$ ) and a fauna described by MoINE et al. (2002) from "zone 4" of the P3 sequence at Nußloch.

\section{Luminescence dating/Experimental details}

The basic principle of luminescence dating is solid state dosimetry of ionising radiation (AITKEN 1998, BötTER-Jensen et al. 2003, Wintle 1997). Luminescence is the light emitted from crystals such as quartz, feldspar or zircon when they are stimulated with heat or light after receiving a natural or artificial radiation dose. As 
Table 2: Dosimetric results of the samples from the section at Schatthausen, as measured by gamma spectrometry. Moisture and alpha efficiency were estimated to $20 \pm 5 \%$ and $0.08 \pm 0.02$ for all samples, respectively.

\begin{tabular}{|lllllll|}
\hline Sample & $\begin{array}{l}\text { Depth Uranium } \\
{[\mathbf{m}]}\end{array}$ & $\begin{array}{l}\text { Thorium } \\
{[\mathbf{p p m}]}\end{array}$ & $\begin{array}{l}\text { Potassium } \\
{[\mathbf{p p m}]}\end{array}$ & $\begin{array}{l}\text { Cosm. } \\
{[\boldsymbol{\mu} \mathbf{H} \mathbf{G} / \mathbf{k a}]}\end{array}$ & $\begin{array}{l}\text { Dose rate } \\
{[\mathbf{G y} / \mathbf{k a}]}\end{array}$ \\
& & & & & & \\
SH1 & 0.30 & $3.09 \pm 0.04$ & $8.89 \pm 0.08$ & $1.28 \pm 0.03$ & $190 \pm 19$ & $3.31 \pm 0.32$ \\
SH2 & 0.50 & $3.20 \pm 0.06$ & $9.00 \pm 0.10$ & $0.79 \pm 0.02$ & $190 \pm 19$ & $2.96 \pm 0.31$ \\
SH3 & 1.10 & $3.07 \pm 0.03$ & $9.34 \pm 0.06$ & $1.16 \pm 0.02$ & $190 \pm 19$ & $3.25 \pm 0.32$ \\
SH4 & 1.40 & $2.94 \pm 0.03$ & $8.63 \pm 0.09$ & $1.16 \pm 0.02$ & $190 \pm 19$ & $3.71 \pm 0.35$ \\
SH5 & 2.40 & $3.41 \pm 0.03$ & $10.04 \pm 0.05$ & $1.27 \pm 0.02$ & $170 \pm 17$ & $3.52 \pm 0.35$ \\
SH6 & 2.65 & $3.53 \pm 0.07$ & $10.79 \pm 0.11$ & $1.23 \pm 0.03$ & $160 \pm 16$ & $3.60 \pm 0.37$ \\
SH7 & 2.65 & $3.07 \pm 0.06$ & $9.72 \pm 0.11$ & $1.23 \pm 0.03$ & $160 \pm 16$ & $3.32 \pm 0.33$ \\
SH8 & 3.10 & $3.19 \pm 0.05$ & $9.56 \pm 0.09$ & $1.23 \pm 0.03$ & $150 \pm 15$ & $3.33 \pm 0.33$ \\
SH9 & 3.80 & $3.33 \pm 0.03$ & $9.62 \pm 0.06$ & $1.19 \pm 0.02$ & $140 \pm 14$ & $3.35 \pm 0.34$ \\
SH10 & 3.90 & $3.33 \pm 0.03$ & $9.72 \pm 0.06$ & $1.09 \pm 0.01$ & $130 \pm 13$ & $3.86 \pm 0.38$ \\
SH11 & 4.60 & $3.44 \pm 0.07$ & $11.51 \pm 0.12$ & $1.52 \pm 0.04$ & $140 \pm 14$ & $3.24 \pm 0.33$ \\
SH12 & 4.65 & $3.52 \pm 0.06$ & $11.21 \pm 0.12$ & $1.53 \pm 0.03$ & $130 \pm 13$ & $3.85 \pm 0.38$ \\
SH13 & 5.90 & $3.94 \pm 0.04$ & $12.86 \pm 0.10$ & $1.50 \pm 0.02$ & $120 \pm 12$ & $4.15 \pm 0.42$ \\
SH14 & 6.10 & $3.97 \pm 0.05$ & $12.96 \pm 0.12$ & $1.40 \pm 0.03$ & $120 \pm 12$ & $4.09 \pm 0.42$ \\
SH15 & 6.20 & $3.90 \pm 0.05$ & $12.61 \pm 0.12$ & $1.40 \pm 0.03$ & $120 \pm 12$ & $4.03 \pm 0.42$ \\
SH16 & 6.70 & $3.81 \pm 0.04$ & $12.41 \pm 0.10$ & $1.44 \pm 0.02$ & $110 \pm 11$ & $3.99 \pm 0.41$ \\
\hline
\end{tabular}

Table 3: Equivalent dose values in Gray (Gy) and IRSL and TL age estimates in 1.000 years.

\begin{tabular}{|c|c|c|c|c|}
\hline \multirow[t]{2}{*}{ Sample } & \multicolumn{2}{|c|}{ Palaeodose in [Gy] } & \multicolumn{2}{|c|}{ Age in 1,000 years } \\
\hline & TL & IRSL & TL & IRSL \\
\hline SH1 & $41.9 \pm 3.0$ & $41.4 \pm 0.6$ & $12.7 \pm 1.5$ & $12.5 \pm 1.2$ \\
\hline $\mathrm{SH} 2$ & & $50.4 \pm 1.5$ & & $17.0 \pm 1.8$ \\
\hline $\mathrm{SH} 3$ & $63.3 \pm 4.1$ & $44.3 \pm 1.1$ & $19.5 \pm 2.3$ & $13.6 \pm 1.4$ \\
\hline SH4 & & $51.4 \pm 3.8$ & & $13.9 \pm 1.7$ \\
\hline SH5 & $81.7 \pm 5.6$ & $71.3 \pm 3.2$ & $23.2 \pm 2.8$ & $20.3 \pm 2.2$ \\
\hline SH6 & & $52.5 \pm 6.3$ & & $14.6 \pm 2.3$ \\
\hline SH7 & & $44.8 \pm 3.8$ & & $13.5 \pm 1.8$ \\
\hline SH8 & & $53.2 \pm 2.3$ & & $16.0 \pm 1.7$ \\
\hline SH9 & $54.6 \pm 4.6$ & $58.1 \pm 1.2$ & $16.3 \pm 2.1$ & $17.4 \pm 1.8$ \\
\hline SH10 & $55.1 \pm 1.3$ & $53.2 \pm 0.9$ & $17.0 \pm 1.8$ & $16.4 \pm 1.7$ \\
\hline SH11 & & $148.3 \pm 3.8$ & & $38.5 \pm 4.0$ \\
\hline SH12 & & $198.9 \pm 3.9$ & & $51.6 \pm 5.2$ \\
\hline SH13 & & $188.1 \pm 4.1$ & & $45.4 \pm 4.7$ \\
\hline SH14 & & $214.6 \pm 3.3$ & & $52.5 \pm 5.5$ \\
\hline SH15 & & $191.6 \pm 2.3$ & & $47.6 \pm 4.9$ \\
\hline SH16 & & $285.6 \pm 3.7$ & & $71.5 \pm 7.4$ \\
\hline
\end{tabular}


a result of natural radiation in sediments, the number of electrons lodged at traps caused by crystal lattice defects, increases with time and dose until all traps are filled and saturation is reached. The equivalent dose is a measure of the past radiation energy absorbed in natural dosimeters like quartz and feldspar minerals and, in combination with the dose rate, which is the rate of radiation absorbed per unit time, yields the time elapsed since the last exposure to sunlight. In this study, the equivalent dose is determined in the laboratory by the Multiple Aliquot Additive Dose protocol (MAAD)

An important assumption of luminescence dating techniques is that the mineral grains were sufficiently long exposed to daylight/sunlight prior to deposition. About 3-5 minutes and 46 hours are required to reset the IRSL signal and the TL signal to zero or to the unbleachable residual, respectively. A further important dating assumption requires no charge loss, e.g. anomalous fading (WINTLE 1973), within the period to be dated.

In this study, IRSL and TL measurements were carried out on sixteen samples. Polymineral fine-grained material $(4-11 \mu \mathrm{m})$ was prepared for the determination of equivalent dose, as described by FrECHEN et al. (1996). The samples were either gamma irradiated by a ${ }^{60} \mathrm{Co}$ source or beta irradiated by a ${ }^{90} \mathrm{Sr}$ beta source in at least seven dose steps with five discs each and a maximum radiation dose of 750 Gray (Gy). All discs were stored at room temperature for at least four to six weeks after irradiation. The irradiated samples were preheated for 1 minute at $230^{\circ} \mathrm{C}$ before infrared and thermal stimulation. Equivalent dose values were determined using IRSL and TL. A Schott BG39/Corning 7-59 filter combination was placed between photomultiplier and aliquots for both IRSL and TL measurements. A 10s IR exposure was followed by heating up the discs to $450^{\circ} \mathrm{C}$ with a heating rate of $5^{\circ} \mathrm{C} / \mathrm{s}$ to obtain their IRSL and TL signals. Five discs of each sample were exposed to an unfiltered solar simulator lamp (dr hönle 2) for three hours to determine the residual TL signal. The equivalent dose was obtained by integrating the 1-10s region of the IRSL decay curves. The equivalent dose values of the TL signal were obtained by integrating a $100^{\circ} \mathrm{C}$ temperature region between 280 and $420^{\circ} \mathrm{C}$ of the glow curves using an exponential fit. Alpha efficiency was estimated to a mean value of $0.08 \pm 0.02$ for all samples (cp. LANG et al. 2003). Dose rates for all samples were calculated from potassium, uranium and thorium contents, as measured by gamma spectrometry (N-type high purity Germanium (HPGe) detector with $25 \%$ relative efficiency) in the laboratory, assuming radioactive equilibrium for the decay chains. Cosmic dose rate was corrected for the altitude and sediment thickness, as described by Aitken (1985) and Prescott \& HutTon (1994). The natural moisture content of the sediment was estimated to $20 \pm 5 \%$ for all samples. Potential problems encountered to an underestimation of the moisture owing to permafrost conditions during the geological past were described by FreCHEN et al. (2001).

\section{Dating results}

Uranium, thorium and potassium contents range from 2.9 to $4.0 \mathrm{ppm}, 8.6$ to $12.9 \mathrm{ppm}$ and from 0.8 to $1.5 \%$, respectively, resulting in a dose rate between 2.96 and $4.15 \mathrm{~Gy} / \mathrm{ka}$. The mean dose rate is $3.60 \mathrm{~Gy} / \mathrm{ka}$ and is typical for Central European loess (cp. FRECHEN et al. 1999, 2001). Pedosediments and palaeosols from the lower part of the profile have a higher dose rate, most likely owing to the higher clay content. These dosimetric results are in excellent agreement with those of a previous study on loess from the nearby Nußloch section (LANG et al. 2003).

The IRSL equivalent dose values increase with depth from 41 to 286 Gray (Gy). Both, IRSL and TL equivalent dose values were determined for five samples and are in agreement within the 1-sigma standard deviation for three samples. Sample SH5 was taken from a Cryic Gleysol and shows a significantly higher TL equivalent dose value, if compared to IRSL, indicating most likely a short-distance transport and insufficient bleaching prior to deposition for TL in any case, but also for IRSL.

The silt of the upper part of the Bt horizon yielded an IRSL age estimate of $71.5 \pm 7.4 \mathrm{ka}$. Samples from the humic-rich horizon and the $\mathrm{Bw}$ horizon gave IRSL age estimates ranging 
from $52.5 \pm 5.5$ to $47.6 \pm 4.9 \mathrm{ka}$. The weighted mean age of these samples yielded $48.9 \pm 2.5 \mathrm{ka}$ $(n=4)$ for this part of the sequence. In order to test the reliability of the weighted mean ages, the chi square test was applied. This statistical approach allows to check, whether the single data points (n) belong to the same cumulative distribution. The chi square test gave $1.3(\mathrm{n}=4)$, which is acceptable. The Cryic Gleysol (SH11) above the Bw horizon was also sampled and gave an IRSL age estimate of $38.5 \pm 4.0 \mathrm{ka}$.

The upper $5 \mathrm{~m}$ of the loess sequence correlates most likely with the Late Glacial of the Upper Würmian (MIS 2). Ten IRSL age estimates are available and range from $17.4 \pm 1.8$ to $13.5 \pm 1.8$ $\mathrm{ka}$. The TL age estimates are in agreement with those from IRSL and range from $15.8 \pm 1.2$ to $12.7 \pm 1.2 \mathrm{ka}$ excluding samples $\mathrm{SH} 3$ and SH5. The weighted mean IRSL age estimate is $15.2 \pm 0.8 \mathrm{ka}(\mathrm{n}=8)$ and the chi square test gave $6.1(\mathrm{n}=8)$, which is acceptable. Two samples were excluded from the interpretation in order to fulfil the chi square test. The first sample excluded was taken from a solifluction layer (SH5) and most likely was insufficiently bleached prior to deposition. The second sample was most likely contaminated with younger material by bioturbation processes close to the present surface (SH1).

\section{Discussion}

At the Schatthausen section, the oldest studied loess sediments are at least of penultimate glacial deposition age (Terhorst et al. 2001). A well-developed Bt horizon (SH 17) of a Luvisol superimposes the penultimate glacial loess (SH18). The truncated Bt horizon correlates most likely with the last interglacial, the Eemian interglacial and MIS 5e.

The overlying weak Bt horizon yielded an IRSL age estimate of $71.5 \pm 7.4 \mathrm{ka} \mathrm{BP}$ (SH 16). In the Neckar area, the sections at Böckingen and at Bönnigheim located about $65 \mathrm{~km}$ to the south-east of Schatthausen were investigated by a luminescence dating approach (FRECHEN 1999; ZÖLLER \& WAGNER, 1990). The sediments from below and above a chernozem, correlating to the "Mosbacher Humuszonen" sensu Semmel (1968), gave IRSL age estimates rang- ing from $68.7 \pm 8.2 \mathrm{ka}$ to $55.7 \pm 4.8 \mathrm{ka}$ at the Böckingen section, respectively. These results are in agreement with those determined for the loess/palaeosol sequence at the Bönnigheim section. In general, the uppermost chernozem in the Neckar area correlates most likely with the uppermost "Mosbacher Humuszone" sensu Semmel (1968), whereas the older humic-rich horizons (Middle and Lower "Mosbacher Humuszone" sensu Semmel, 1968) are not recorded. At the Mainz-Weisenau section situated in the Mainz basin, the loess from below the uppermost chernozem gave an IRSL age estimate of $72.4 \pm 12.3 \mathrm{ka}$ (FRECHEN \& PREUSSER 1996; FreChEN 1999). These luminescence results indicate that soil formation did occur during the Lower Würmian or during the early Middle Würmian.

In the Middle Rhine area, the sediments sandwiching the Lower Würmian BtAh horizon at the Tönchesberg section and the Upper Pedocomplex at the Koblenz-Metternich section gave IRSL age estimates ranging from 75 to 64 ka and from 77 to $67 \mathrm{ka}$, respectively (BoENIGK \& FRECHEN 2001). It is very likely that the BtAh from Tönchesberg and the Upper Pedocomplex from Koblenz-Metternich correlate with MIS 5a. At both sections, Ah horizons postdating MIS 5a are intercalated in the loess record.

At the Nußloch section, LANG et al. (2003) determined an IRSL age estimate of $122 \pm 18 \mathrm{ka}$ for the penultimate glacial loess from below the Bt horizon (cp. TL age estimates determined by ZöLLER et al. 1988). A sample taken from the lower part of the Bt horizon yielded an IRSL age estimate of $62 \pm 10 \mathrm{ka}$, which was interpreted as considerably underestimated by ANTOINE et al. (2001). Three distinct horizons of humicrich material were described from the section at Nußloch (ANTOINE et al. 2001), however not exposed at the section under study.

At the section at Schatthausen, the palaeopedological investigations show clearly, that two different $\mathrm{Bt}$ horizons can be distinguished. The upper pedocomplex (SH16 - SH13) gives evidence for a later soil forming period, which took place after the Eemian pedogenesis and postdates the erosional phase at the beginning of the last glacial period. The palaeopedological results coincide well with the IRSL-dating 


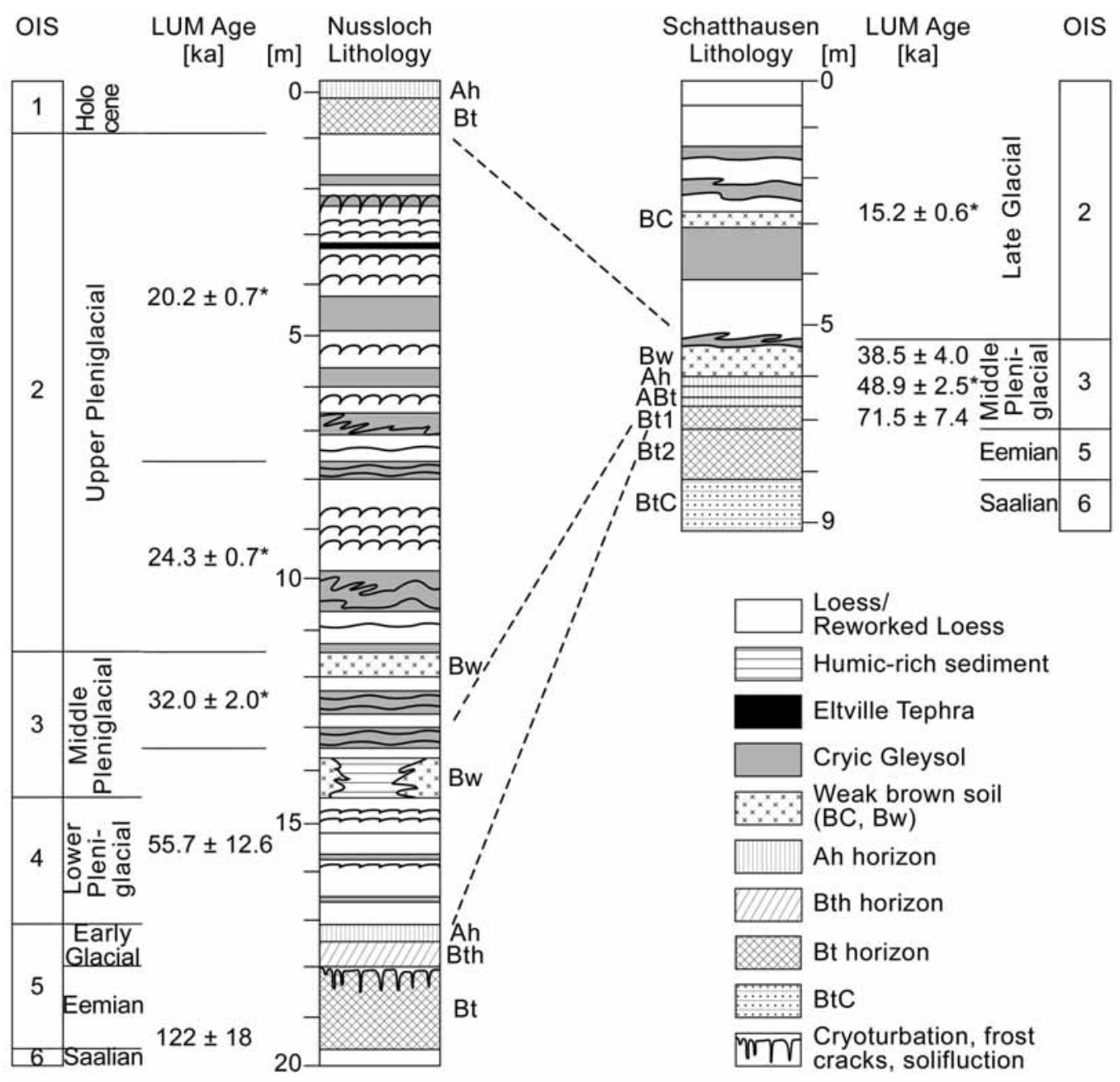

Fig. 3: Chronological interpretation and comparison of the two loess/paleosol sequences from the sections at Nussloch and Schatthausen. The lithological sequence of the Nußloch section is modified after ANTOINE et al. (2001), the weighted mean ages were calculated from the results of this study and LANG et al. (2003).

of $71.5 \pm 7.4 \mathrm{ka}$ for the sedimentation of the parent material of the younger soil. The sharp and clear boundary between the Eemian $\mathrm{Bt}$ horizon (SH17) and the overlying interstadial Bt horizon (SH16) implies the formation by an erosional process. The fact that rounded charcoals have been redeposited in combination with rounded clay fragments in thin sections (forthcoming study) proves that in this position pre-weathered material was accumulated on top of the Eemian soil. There is no evidence of similar features inside the well-developed interglacial soil. Furthermore, variations in clay content and in the intensity of clay cutans vary strongly between SH17 and the overlying pedocomplex. After TerHORST et al. (2001), the Eemian soil contains $32.7 \%$ clay, whereas the clay content of the superimposed $\mathrm{Bt}$ horizon is reduced to $20 \%$ and even further to $18 \%$ in the AhE horizon of SH15. Soil forming processes inside the pedocomplex are additionally reflected in the record of magnetic susceptibility showing a decrease inside the leached upper parts of the pedocomplex (SH13, SH14) and an increase in the weakly developed interstadial Bt horizon (SH16, Terhorst et al. 2001). The 
above discussion and the results of the IRSL dating study underline the interpretation of different soil forming phases, which differ in chronology and in intensity of pedogenesis, one reflecting interglacial conditions the other interstadial ones. Additionally, the polygenetic and interstadial origin of the pedocomplex SH16 - SH13 is yielded by the composition of phytoliths in this profile section. ZöLLER et al. (2004) also discussed a Bt horizon buried under last glacial loess, which might be younger than the last interglacial period. The fact of superimposing palaeosols, weathering intensity and pedogenesis in pre-weathered soil sediments (cf. STEPHAN 2000) should be taken more seriously into account when interpreting polygenetic palaeosols.

The Middle Pleniglacial (Middle Würmian) sediments yielded IRSL age estimates ranging from $71.5 \pm 7.4$ to $38.4 \pm 4.0 \mathrm{ka}$ at the Schatthausen section. At Nußloch, the Lower Pleniglacial deposits consist of sandy and loessic sediments subdivided by a Cryic Gleysol and a Gelic Cambisol. There, loessic samples yielded IRSL age estimates ranging from $61 \pm 10 \mathrm{ka}$ to $56 \pm 13 \mathrm{ka}$ (LANG et al. 2003). The Middle Pleniglacial deposits of Nußloch consist of loess subdivided by at least one Cambisol and one Cryic Gleysol, which formed between 55 $-40 \mathrm{ka}$ (LANG et al. 2003). These results are in excellent agreement with those of the Middle Pleniglacial record at the Schatthausen section. At Nußloch, the IRSL age estimates from the loess sandwiching the uppermost palaeosol gave IRSL age estimates ranging from $34 \pm 3$ $\mathrm{ka}$ to $30 \pm 4 \mathrm{ka}$. It is very likely that this palaeosol correlates with the Denekamp Interstadial ("Lohner Boden" sensu Semmel 1967). The Bw horizon from the section at Schatthausen very likely correlates with the oldest Middle Würmian palaeosol from Nußloch, as evidenced by an IRSL age estimate of $50.5 \pm 3.8 \mathrm{ka}$ for the sediments of the BC horizon and an IRSL age estimate of $38.5 \pm 4.0 \mathrm{ka}$ for the Cryic Gleysol covering the $\mathrm{Bw}$ horizon (Figs. 2 and 3). At the Böckingen and Bönnigheim sections, the lower Bw horizon, which correlates with the Middle Würmian, gave IRSL estimates ranging from $43.5 \pm 6.0$ to $28.7 \pm 2.9 \mathrm{ka}$ and from $44.4 \pm 6.3$ to $29.6 \pm 5.0 \mathrm{ka}$, respectively (FRECHEN 1999).
In Upper Austria, loess from below a contemporaneous $\mathrm{Bw}$ horizon yielded an IRSL age estimate of $46.5 \pm 3.4 \mathrm{ka}$ at the Trindorf section (Terhorst et al. 2002, 2003).

It is likely to correlate this Bw horizon ("Böckinger Boden" sensu BiBus 1989) with the Moershoofd or Hengelo interstadial (cp. BeHRE 1989) or both. An equivalent of the Denekamp interstadial (MIS 3) is not exposed at the Schatthausen section but very likely exposed at the Nußloch section (cp. LANG et al. 2003).

During the Upper Pleniglacial, loess accumulated more than $10 \mathrm{~m}$ thick at Nußloch. There, single loess layers vary in thickness from 0.5 to $2.0 \mathrm{~m}$ (Antorne et al. 2001). The loess is subdivided by numerous Cryic Gleysols (Gelic Gleysols), which are more or less cryoturbated and/or were subject to solifluction. The Gleysols correlate with slightly more humid periods when dust accumulation decreased. This loess record indicates considerable fluctuations in response to variations in wind dynamics and the intensity of deflation in the Rhine valley near Nußloch (Antoine et al. 2001). The loess record at Nußloch gives evidence for at least two major pulses of loess accumulation between 27-25 ka and between 22-19 ka (LANG et al. 2003), which are contemporary with the main Upper Pleniglacial dust peaks recorded in the Greenland ice core (Northgrip Members 2004). LANG et al. (2003) and Hatté et al. (2001) provided IRSL and ${ }^{14} \mathrm{C}$ dating results for the loess/paleosol sequence from Nußloch, which are in excellent agreement for the time period of the past 30,000 years. This Upper Würmian (Upper Pleniglacial) loess/palaeosol sequence gives a more or less continuous record about $11.30 \mathrm{~m}$ thick. The radiocarbon ages and the IRSL age estimates range from $26.0 \pm 4.0 \mathrm{ka}$ to $18.2 \pm 3.7 \mathrm{ka}$ for the Upper Würmian part of the sequence. The IRSL age estimates from Nußloch do not indicate any age increase with depth and, thus suggest a fast accumulation of dust most likely during two Pleniglacial periods, as confirmed by the two weighted mean ages of $20.6 \pm 0.6 \mathrm{ka}(\mathrm{n}=14)$ and $24.3 \pm 0.7 \mathrm{ka}$ $(n=4)$, respectively (Fig. 3). The chi-square test gave $7.3(n=14)$ and $0.4(n=4)$, which is acceptable. At the Schatthausen section, this part of the Upper Würmian loess record is not exposed 
in the profile under study. The younger Middle Würmian/Middle Pleniglacial sediments are eroded. The Late Glacial loess is subdivided by three Cryic Gleysols and a weak brownish $\mathrm{BC}$ horizon. The sediment was accumulated between $17.4 \pm 1.8$ and $13.5 \pm 1.8 \mathrm{ka}$. A weighted mean age of $15.2 \pm 0.6 \mathrm{ka}$ was determined for this loess, which most likely correlates to a Late Glacial pulse of dust sedimentation, as described in the Greenland ice core (NORTHGRIP Members 2004). The IRSL results do not show age increase with depth indicating a large mass accumulation rate during the late glacial, most likely $>1.5 \mathrm{~m} / \mathrm{ka}$. The duration of the increased dust accumulation period cannot be determined precisely owing to the analytical error of luminescence dating technique and its resulting 1-sigma standard deviation. It can be assumed that the upper $5 \mathrm{~m}$ of the loess record at Schatthausen correlates with the Late Glacial and postdates the eruption of the Eltviller tephra. A weighted mean age for the loess sandwiching the Eltville Tephra at the Ockenfels section in the Middle Rhine area (Preusser \& FreCHEN 1999) and at the Mainz-Weisenau section (Frechen \& Preusser 1996) gave $19.8 \pm 0.7$ ka $(n=10)$. A similar weighted mean age of $19.5-19.0 \mathrm{ka}$ was calculated for the Eltville Tephra from Nußloch by LANG et al. (2003). The chronostratigraphic position of the brown $\mathrm{BC}$ horizon ( $\mathrm{SH} 6$ and 7) correlates most likely with the one from above the Eltviller tephra in the loess/palaeosol sequence at the Ockenfels section in the Middle Rhine area, as evidenced by IRSL age estimates and loess stratigraphy (Bibus 1989; Preusser \& Frechen 1999).

Four radiocarbon ages are available for the upper part of the sequence (SH9 - SH1), those are $24,510 \pm 190 \mathrm{BP}(\mathrm{UtC} 10628)$ and $23.990 \pm 160$ BP (UtC10626) for sample SH9 and calibrated ${ }^{14} \mathrm{C}$ ages of $10,220-10,183$ cal BP (UtC 10625) and 10,146-10,139 cal BP (UtC 10524) for samples SH1 and SH3. The latter radiocarbon dates are not consistent with the IRSL age estimates. The uncalibrated radiocarbon ages of 24,510 BP and 23,390 BP are within the 1-sigma standard deviation in agreement with the IRSL age estimates. The samples of calcified root cells of $\mathrm{SH} 1$ and $\mathrm{SH} 3$ belong to the beginning of the Holocene period and mark first carbonate leaching processes. Postsegregational recrystallization can result in ${ }^{14} \mathrm{C}$ ages of pedogenic carbonate that are too young (Pustovoytov \& Terhorst 2004, Amundson et al. 1994). Furthermore, HAтtÉ et al. (1999, 2001) underlined that ${ }^{14} \mathrm{C}$ ages have to be taken cautiously owing to carbonate recrystallisation in snails from the loess.

\section{Conclusion}

The loess/palaeosol sequence from the section at Schatthausen gives evidence for a younger Bt horizon superimposing the last interglacial palaeosol. This result requires a more careful investigation of polygenetic superimposed palaeosols in order to avoid misinterpretation of the chronostratigraphic position (cp. TERHORST \& OTTNER 2003; ZöLler et al. 2004). The humic horizon and the underlying $\mathrm{Bt}$ horizon form a pedocomplex designated to have been developed during at least two Lower or Middle Pleniglacial periods, as suggested by palaeopedology, phytoliths and chronology. The sediment of the lower and upper part of this pedocomplex was deposited around $70 \mathrm{ka}$ and between 50 and $45 \mathrm{ka}$, respectively. The lower part of the sequence shows discontinuities in sedimentation and pedogenesis.

The youngest Middle Würmian interstadial, the Denekamp interstadial, is not recorded in Schatthausen. However, there is evidence for an older MiddleWürmian palaeosol, which is supposed to correlate with the "Böckinger Boden" sensu BiBus (1989) by means of pedological properties and IRSL dating results. The sediment gave an IRSL age estimate of $51.6 \pm 5.2 \mathrm{ka}$, which is in agreement with IRSL age estimates from other loess sequences in the Neckar-Main area (cp. FreChEN 1999).

Three luminescence age clusters can be distinguished for the loess/palaeosol sequence at the section at Schatthausen. These are from the youngest to the oldest: the Late glacial loess (MIS 2) with a weighted mean IRSL age estimate of $15.2 \pm 0.6 \mathrm{ka}$, the Middle Pleniglacial (MIS 3) with a weighted mean age of $48.9 \pm 2.5 \mathrm{ka}$ and a Lower Würmian record (MIS 4/MIS 5) with a deposition age of $>70 \mathrm{ka} \mathrm{BP}$. The chronological investigations are in agreement with those from 
the nearby Nußloch section and complement the idealized sequence with the Late Glacial loess and its intercalated tundra gleys. Furthermore, this loess record shows an excellent agreement with the GRIP dust record for the late Glacial period The brownish $\mathrm{BC}$ horizon formed during the Late Glacial was also described in similar stratigraphic position at the Ockenfels section in the Middle Rhine area (BiBus 1980).

\section{Acknowledgment}

Funding of the Deutsche Forschungsgemeinschaft (HI 643/2-3) in the frame of the project "Sediment budget of Pliocene and Quaternary sediments in the Upper Rhine area" is appreciated. Prof. Dr. A. Semmel and Prof. Dr. L. ZöLLER were thanked for valuable comments on an earlier version of the manuscript.

\section{References}

Aitken, M.J. (1985): Thermoluminescence Dating. - 359 S.; Oxford (Oxford University Press).

AitKen, M.J. (1998). Introduction to Optical Dating. - 267 S.; Oxford (Oxford University Press).

Amundson, R., Wang, Y., Chadwick, O., Trumbore, S., McFadden, L., McDonald, E., Wells, S. \& De Niro, M. (1994): Factors and processes governing the ${ }^{14} \mathrm{C}$ content of carbonate in desert soils. - Earth and Planetary Science Letters, 125: 385-405; Amsterdam.

Antoine, P., Rousseau, D.D., Zöller, L., Lang, A., Munaut, A.V., Hatté, C. \& Fontugne, M. (2001): High-resolution record of the last Interglacial-glacial cycle in the Nussloch loess-palaeosol sequences, Upper Rhine Area, Germany. - Quaternary International, 76/77: 211-229; Oxford.

Aoust, V. de (1857): Observations sur un terrain d'origine météorique ou de transport aerien qui existe au Mexique et sur le phénomène des trombes de poussière auquel il doit principalement son origine. - Geol. Soc. France, Full., 2d, Ser., 2: 129-139; Paris.

Behre, K. (1989): Biostratigraphy of the last glacial period in Europe. - Quaternary Science Reviews, 8: 25-44; Oxford.

Bente, B. \& Löscher, M. (1987): Sedimentologische, pedologische und stratigraphische Un- tersuchungen an Lössen südlich Heidelberg. - Göttinger Geographische Beihefte, 84: 9-17; Göttingen.

BiBus, E. (1974): Abtragungs- und Bodenbildungsphasen im Rißlöß. - Eiszeitalter und Gegenwart, 25: 166-182; Öhringen.

BiBus, E. (1980): Zur Relief-, Boden- und Sedimententwicklung am unteren Mittelrhein. - Frankfurter Geowissenschaftliche Arbeiten, Serie D, 1: 1-296; Frankfurt a. M.

BiBus, E. (Hrsg.) (1989): Paläoböden im mittleren Neckarbecken unter besonderer Berücksichtigung von Lößstratigraphie und Paläoböden. - Exkursionsführer, 8. Tagung des Arbeitskreises „Paläoböden“ der Deutschen Bodenkundl. Gesellschaft. - Heilbronn.

Bibus, E. (1995): Exkursion C8, Weser-BodenseeTraverse, Bereich Süddeutschland. In: SCHIRMER, W. (Hrsg.): Quaternary Field Trips in Central Europe, 1: 459-470; München (Pfeil).

Bibus, E., Bludau, W., Bross, C. \& Rähle, W. (1996): Der Altwürm- und Rißabschnitt im Profil Mainz-Weisenau und die Eigenschaften der Mosbacher Humuszonen. - Frankfurter geowissenschaftliche Arbeiten, Serie D, 20: 21-52; Frankfurt a. M.

BoenigK, W. \& Frechen, M. (2001): The loess record in sections at Koblenz-Metternich and Tönchesberg in the Middle Rhine Area. - Quaternary International, 76/77: 201-209; Oxford.

Boetter-Jensen, L., McKeever, S.W.S. \& Wintle, A.G. (2003): Optically stimulated luminescence dosimetry. - 404 S.; Amsterdam (Elsevier).

Frechen, M. (1994): Thermolumineszenz-Datierungen an Lössen des Tönchesberges aus der Osteifel. - Eiszeitalter und Gegenwart, 44: 7993; Stuttgart.

Frechen, M. (1999): Upper Pleistocene loess stratigraphy in Southern Germany. - Quaternary Science Reviews, 18: 243-269; Oxford.

Frechen, M., Horváth, E. \& Gábris, G. (1997): Geochronology of Middle and Upper Pleistocene loess sections in Hungary. - Quaternary Research, 48: 291-312; Washington.

Frechen, M., Oches, E.A. \& Kohfeld, K.E. (2003): Loess in Europe - mass accumulation rates during the Last Glacial Period. - Quaternary Science Reviews, 22: 1835-1857; Oxford.

Frechen, M. \& Preusser, F. (1996): Kombinierte Lumineszenz-Datierungen am Beispiel des 
Lößprofils Mainz-Weisenau. - Frankfurter geowissenschaftliche Arbeiten, Serie D, 20: 53-66; Frankfurt a. M.

Frechen, M., Vliet Lanoe, B.v. \& Van den Haute, P. (2001): The Upper Pleistocene loess record at Harmignies/Belgium - High resolution terrestrial archive of climate forcing. - Palaeogeography Palaeoclimatology Palaeoecology, 173: 175195; Amsterdam.

Frechen, M., Schweitzer, U. \& Zander, A. (1996): Improvements in sample preparation for the fine grain technique. - Ancient TL, 14/2: 15-17; Clermont-Ferrand.

Frechen, M., Zander, A., Cilek, V. \& Lozek, V. (1999): Loess chronology of the last interglacial/ glacial cycle in Bohemia and Moravia/Czech Republic. - Quaternary Science Reviews, 18: 1467-1493; Oxford.

Gerasimova, M.I., Gubin, S.V. \& Shoba, A.A. (1996): Soils of Russia and adjacent countries: geography and micromorphology. - 204 S.; Moscow (Miedema).

Hatté, C., Antoine, P., Fontugne, M., Rousseau, D.D., Tisnérat-Laborde, N. \& Zöller, L. (1999): New chronology and organic matter $\delta^{13} \mathrm{C}$ paleoclimatic significance of Nußloch loess sequence (Rhine Valley, Germany). - Quaternary International, 62: 85-91; Oxford.

Hatté, C., Antoine, P., Fontugne, M., Lang, A., Rousseau, D.D. \& Zöller, L. (2001): $\delta^{13} \mathrm{C}$ of loess organic matter as a potential proxy for paleoprecipitation reconstruction. - Quaternary Research, 55: 33-38; Washington.

Lang, A., Hatté, C., Rousseau, D.D., Antoine, P., Fontugne, M., Zöller, L. \& Нambach, U. (2003): High-resolution chronologies for loess: comparing AMS ${ }^{14} \mathrm{C}$ and optical dating results. - Quaternary Science Reviews, 22: 953-959; Oxford.

LeONHARD, K.C. v. (1823/24): Charakteristik der Felsarten. - 3: 772 S.; Heidelberg (Engelmann).

LozeK, V. (1964): Quartärmollusken der Tschechoslowakei. - Rozpravy Ustr. ust. geol., 31: 1-374; Prague.

Lyell, C. (1834): Observations on the loamy deposits called "loess" of the basin of the Rhine. - Edinburgh New Philosophical Journal, 17: 110-113, 118-120; Edinburgh.

Moine, O., Rousseau, D.-D., Antoine, P. \& Hatté, C. (2002): Mise en évidence d'événements cli- matiques rapides par les faunes de mollusques terrestres des loess Weichseliens de Nussloch (Allemagne). - Quaternaire, 13: 209-217; Paris.

Northgrip Members (2004): High-resolution record of Northern Hemisphere climate extending into the last interglacial period. - Nature, 431: 147151; Oxford.

PéCsi, M., \& Richter, G. (1996): Löss: Herkunft - Gliederung - Landschaften. - Zeitschrift für Geomorphologie, Neu Folge Supplementband, 98: 1-392; Berlin.

Prescott, J.R. \& Hutton, J.T. (1994): Cosmic ray contributions to dose rates for luminescence and ESR dating: large depths and long-term time variations. - Radiation Measurements, 23: 497500; Oxford.

Preusser, F. \& Frechen, M. (1999): Chronostratigraphie der oberweichselzeitlichen Lößabfolge von Ockenfels (Mittelrhein). - In: BECKER-HAUMANN, R. \& FRECHEN, M. (Hrsg.): Terrestrische Quartärgeologie: 475 S.; Köln (logabook).

Pustovoytov, K. \& Terhorst, B. (2004): An isotopic study of a late Quaternary loess-paleosol sequence in SW Germany. - Revista Mexicana de Ciencas Geológicas, 21/1: 88 - 93, Mexico (http: //satori.geociencias.unam.mx/21-1.htm).

Richthofen, F. v. (1878): Bemerkungen zur Lößbildung. - Verh. Geol. Reichsanst. Berlin: 1-13; Berlin.

RICKEN, W. (1983): Mittel- und jungpleistozäne Lößdecken im südwestlichen Harzvorland - Stratigraphie, Paläopedologie und Konnektierung in Flußterrassen. - Catena Supplement, 3: 95-138; New York.

RoHDEnBurg, H. (1968): Jungpleistozäne Hangformung in Mitteleuropa - Beiträge zur Kenntnis, Deutung und Bedeutung ihrer räumlichen und zeitlichen Differenzierung. - Göttinger bodenkundliche Berichte, 6: 2-103; Göttingen.

Rohdenburg, H. \& Meyer, B. (1966): Zur Feinstratigraphie und Paläopedologie des Jungpleistozäns nach Untersuchungen an südniedersächsischen und nordhessischen Lößprofilen. - Mitteilungen Deutsche bodenkundliche Gesellschaft, 5: 1135; Göttingen.

Rohdenburg, H. \& Semmel, A. (1971): Bemerkungen zur Stratigraphie des Würmlösses in Mitteleuropa. - Notizblatt des hessischen Landesamtes für Bodenforschung, 99: 246-252; Wiesbaden.

RöSNER, U. (1990): Die Mainfränkische Lößprovinz. 
- Mitteilungen fränkische geographische Gesellschaft, 37: 1-307; Erlangen.

Schönhals, E., Rohdenburg, H. \& Semmel, A. (1964): Ergebnisse neuerer Untersuchungen zur Würmlöß-Gliederung in Hessen. - Eiszeitalter und Gegenwart, 15: 199-206; Öhringen.

Semmel, A. (1967): Neue Fundstellen von vulkanischem Material in Lössen. - Notizblatt Hessisches Landesamt für Bodenforschung, 95: 104-108; Wiesbaden.

Semmel, A. (1968): Studien über den Verlauf jungpleistozäner Formung in Hessen. - Frankfurter geographische Hefte, 45: 1-133; Frankfurt a. M.

Semmel, A. (Hrsg.) (1996): Pleistozäne und holozäne Böden aus Lößsubstraten am Nordrand der Oberrheinischen Tiefebene. - Frankurter geowissenschaftliche Arbeiten, Serie D, 20: 1-144; Frankfurt a. M.

Semmel, A. (1999): Loess section of Mainz-Weisenau. - In: WeIdENFELLER, M. \& ZöLLER, L. (Hrsg.): Loess in the Middle and Upper Rhine area. Field Guide Loessfest '99: 57-69; Bonn.

Stephan, S. (2000): Bt-Horizonte als InterglazialZeiger in den humiden Mittelbreiten: Bildung, Mikromorphologie, Kriterien. - Eiszeitalter und Gegenwart, 50: 95-106; Hannover.

Terhorst, B., Appel, E. \& Werner, A. (2001): Results of paleopedological and magnetic susceptibility analyses in a loess exposure in SWGermany. - Quaternary International, 76-77, 231-240, Oxford.

Terhorst, B., Frechen, M. \& Reitner, J. (2002): Chronostratigraphische Ergebnisse aus Lößprofilen der Inn- und Traun-Hochterrasse in Oberösterreich. - Zeitschrift Geomorphologie N.F., 127: 213-232; Stuttgart.

Terhorst, B. \& Ottner, F. (2003): Polycyclic Luvisols in Northern Italy: Palaeopedological and Clay Mineralogical Characteristics. - Quaternary International, 106-107: 215-231; Oxford.
Terhorst, B, Ottner, F., Poetsch, T., Kellner, A. \& RÄHLE, W. (2003): Pleistozäne Deckschichten auf der Traun-Enns-Platte bei Linz (Oberösterreich). - In: Terhorst, B. (Hrsg.): Exkursionsführer zur 22. Tagung des Arbeitskreises Paläoböden in Oberösterreich. - Tübinger Geowissenschaftl. Arbeiten, Reihe D, 9: 115 - 155; Tübingen.

WintLe, A.G. (1973): Anomalous fading of thermoluminescence in mineral samples. - Nature, 245: 143-144; London.

Wintle, A.G. (1997): Luminescence dating: laboratory procedures and protocols. - Radiation Measurements, 27: 769-817; Pergamon.

WRB (1998): World Reference Base for Soil Resources. - FAO Report 84; Rome.

Zöller, L., Oches, E.A.. \& McCoy, W.D. (1994): Towards a revised chronostratigraphy of loess in Austria with respect to key sections in the Czech Republic and in Hungary. - Quaternary Science Reviews, 13: 465-472; Oxford.

ZÖlLER, L. \& LÖSCHER, M. (1999): The last glacialinterglacial cycle in the loess section at Nussloch and underlying upper Tertiary loams. - In: WEIDENFELLER, M. \& Zöller, L. (Hrsg..): Loess in the Middle and Upper Rhine area. - Field Guide Loessfest '99: 37-50, Bonn.

Zöller, L., Stremme, H.E. \& Wagner, G.A. (1988): Thermolumineszenz-Datierung an Löß-Paläoboden-Sequenzen von Nieder-, Mittel- und Oberrhein. - Chemical Geology (Isot. Geosc. Sect.), 73: 39-62; Heidelberg.

Zöller, L., Rousseau, D.-D., Jäger, K.-D. \& KuKLA, G. (2004): Last interglacial, Lower and Middle Weichselian - a comparative study from the Upper Rhine and Thuringian loess areas. - Zeitschrift Geomorphologie Neue Folge, 48: 1-24; Stuttgart.

ZÖLler, L. \& WAGNER, G.A. (1990): Thermoluminescence dating of loess - recent developments. Quaternary International, 7/8: 119-128, Oxford. 